\title{
Oefening baart niet altijd kunst
}

In mijn opleiding leerde ik veel vaardigheden, maar de meeste heb ik me in de praktijk eigen gemaakt door een combinatie van nieuwsgierigheid, cursussen volgen en een bepaalde mate van durf om nieuwe wegen in te slaan. Dat heeft me naast veel geploeter en vallen en opstaan ook veel plezier opgeleverd.

De eerste keer dat ik orthodontische brackets plaatste kostte mij dat bijna een hele middag. Door mijn ongeoefendheid vlogen de brackets soms als sprinkhanen door de behandelkamer. Bedrijfsmatig volstrekt onrendabel, maar het gaf mij wel een enorme voldoening toen het lukte. De keer daarop ging het al een stuk beter, wat mij stimuleerde om ermee door te gaan.

Ik weet ook nog goed hoe trots ik was na het plaatsen van mijn eerste implantaat. Na afloop bleef ik nog urenlang op de röntgenfoto naar het bevredigende resultaat staren.

Het leren van nieuwe vaardigheden gaat in verschillende fasen. De eerste fase is die van leerling. Je gaat voor de basisbeginselen bij iemand in de leer die het vak beheerst. Dan ga je stapje voor stapje verder. Je gaat van iets kunnen naar iets onder de knie krijgen terwijl je leermeester over je schouder meekijkt.

In fase twee begin je het in de vingers te krijgen. Dat is het moment waarop je je bekwaamheden zelfstandig gaat toepassen in je eigen werkomgeving.

In fase drie beheers je de kunst: je hebt je het vak zodanig eigen gemaakt dat je het meesterschap zou kunnen noemen. In deze fase ben je een geroutineerde vakman geworden die beloond wordt met een registratie in het beroepsregister.

De coryfeeën in het vak die waken over dat register kloppen zichzelf nogal eens als egomane bokito's op de borst over hun eigen aantallen verrichtingen en nemen anderen daarmee de maat: kwantiteit als garantie voor kwaliteit. Dit op grond van de vooronderstelling dat de kwaliteit stijgt naarmate men meer van hetzelfde doet. Dit idée reçue werd gevestigd door het bekende boek The Outliers (de Uitblinkers) van Malcom Gladwell uit 2008 waarin de 10.000-uurregel als normatief wordt aangenomen: wie goed wil worden in iets, moet daar ten minste tienduizend uur voor oefenen. Deze aanname was gebaseerd op een onderzoek onder violisten door de Zweedse psycholoog Anders Ericsson. Hij concludeerde dat voor het behalen van succes oefening doorslaggevender is dan talent. Algemeen wordt dan ook aangenomen dat de kundigheid van bijvoorbeeld een orthopedisch chirurg toeneemt als hij dag in dag uit niets anders doet dan het plaatsen van heupprotheses. Zijn routine neemt weliswaar toe, maar niet persé de kwaliteit van zijn werk. Persoonlijke eigenschappen blijken daarvoor minstens zo belangrijk te zijn, zoals zelfreflexie, kritisch vermogen en de bereidheid om nieuwe uitdagingen aan te gaan (cognitive readiness), of gewoon talent.

Er is veel variatie tussen mensen onderling. Sommigen bereiken een hoog niveau met weinig oefening, terwijl dat anderen nooit lukt ondanks het vele oefenen. De 10.000-uurregel blijkt een mythe. Dat was eigenlijk al bekend bij jachtvliegers tijdens de Tweede Wereldoorlog. Jonge, onervaren piloten van de Britse Royal Air Force werden niet vaker neergeschoten dan hun ervaren collega's die door hun routine minder scherp waren geworden. De leercurve gaat in het begin steil omhoog om daarna af te vlakken en vervolgens langzaam te dalen.

Dit wordt bevestigd door een meta-analyse in het online tijdschrift Psychological Science van juli 2014, gebaseerd op 88 onderzoeken met in totaal elfduizend proefpersonen. Hieruit komt naar voren dat de relatie tussen oefenen en prestatie niet éénduidig positief is, met een klein verschil tussen praktische en cognitieve vaardigheden.

Uitsluitend draaien op routine en daarbij een zo groot mogelijk aantal verrichtingen na te streven kan afstomping in de hand werken en een mens minder prudent en ontvankelijk maken. Als je eenmaal een bedreven routinier bent, dan is het de kunst om iets van het beginnersenthousiasme vast te houden. Goethe zei ooit: 'Diejenigen sind glücklich die etwas vom Kinde gerettet haben'. Wie in deze reddingspoging slaagt, heeft zowel plezier als succes in zijn werk en daarmee stijgt de kwaliteit ervan.

Arthur van Winsen 